\title{
Management guidelines for the conservation of heritage resources in Wakkerstroom, Mpumalanga
}

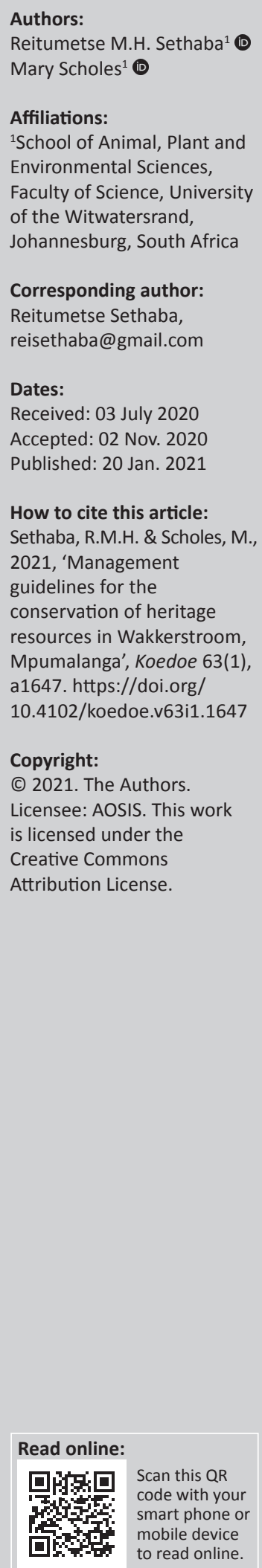

Conservation of heritage resources, both architectural and cultural, focuses on the important of historical context, identity and to provide livelihoods for people. Management and stakeholder engagement are fundamental for conservation. This article describes the contribution of stakeholder perceptions in the development of management guidelines for the conservation of heritage resources in the town of Wakkerstroom, Mpumalanga. The concept of conservation is usually used with reference to the natural heritage; however, this should also include architectural and cultural conservation, in the same location, as is done in many other parts of the world. The study of the combined architectural and cultural heritage in Wakkerstroom is one of the first of such studies in South Africa. The natural heritage resources were identified and a stakeholder map developed after conducting interviews with 27 participants in the township of Esizameleni and 15 participants in the town. Resources identified included the provincial heritage sites of the Wakkerstroom Wetland, the Paul Kruger Bridge, St Mark's Anglican Church and the Old Courthouse Building. Heritage value definitions in the town area were centred on inheritance, whilst township stakeholders valued the identity aspect of heritage. A lack of communication, participation and awareness around heritage conservation was identified as a key issue amongst the communities. In addition, unlike natural heritage conservation, where the Wakkerstroom Natural Heritage Association takes care of the wetland, no organisation was found to be responsible for cultural heritage conservation in the town. The municipality urgently needs to address these concerns by developing an integrated management plan for heritage resource conservation.

Conservation implications: Conservation includes more than just the conservation of natural heritage. The Wakkerstroom Natural Heritage Association (WNHA) manages natural heritage, but there is no organisation managing cultural heritage. Heritage conservation would benefit from the development of an integrated management plan lead by Dr Pixley Ka Isaka Seme Local Municipality together with the identified stakeholders.

Keywords: heritage; conservation; resource management; stakeholder engagement; sustainable communities.

\section{Introduction and background}

The term 'heritage' is used loosely to describe everything that is inherited or handed down to future generations from the past (Lowenthal 2005). Natural heritage resources usually refer to land, water, animals and plants. Cultural heritage resources include buildings, art, traditions and practices of cultural and historical value (Lowenthal 2005). Heritage can also be described as tangible 'a monument, group of buildings, or site of historical, aesthetic, archaeological, scientific, ethnological or anthropological value' (Kirshenblatt-Gimblett 2004); or intangible such as 'all forms of traditional and popular culture such as collective works originating in a given community, and based on tradition' including music, dance and traditional medicine (United Nations Educational, Scientific and Cultural Organisation (Civallero 2007; UNESCO 1989).

Heritage resources have been shown to be important in, amongst other factors, issues of history, identity and maintenance of livelihoods for people in South Africa and the world (Nzama 2009; Parts et al. 2011; Su et al. 2018). Conservation of both natural and cultural heritage provides the benefit of encouraging economic activity through an integrated development plan, one aspect of which could be tourism. Conservation of the natural heritage is often focussed on biodiversity, ecosystem integrity and ecosystem goods and services and seems more tangible than conserving cultural heritage, which has many more components. 
Resource management serves as a tool for resource conservation, enabling the protection of resources through the monitoring of use, preventing damage to, and overexploitation of, valued resources (Cleere 2010). Plans for sustainable resource management must consider humanenvironment interactions. Understanding these interactions and what influences them is an important component of effective management strategies. Stakeholder engagement is an important process in resource management, representing inclusive management strategies and has been on an incremental trajectory in the environmental sector since the 1980s (Young et al. 2013). The United Nations Conference on Environment and Development (UNCED) identified stakeholder engagement in management and decisionmaking as one of the steps instrumental in the move towards sustainable development (UNCED 1992). The argument for this has been mainly around bringing different perspectives in the form of knowledge and values into the processes of decision-making, in order to make better decisions where people and development are concerned (Chirikure et al. 2008; Renn 2006). Studies have shown that where effective stakeholder engagement was carried out, trust is built, communication and decision-making processes are improved (Munton 2003) and there is rapid adoption of management strategies in communities (Beierle \& Konisky 2001; Sultana \& Abeyasekera 2008). Effective communication and consultation between management and other stakeholders are also important considerations for successful stakeholder engagement. This is especially true in areas where activities such as tourism intersect with heritage conservation, potentially creating conflicts. Communication and consultation are vital to the successful and sustainable execution of activities (Aas, Ladkin \& Fletcher 2005; Keitumetse 2011; Peters 1999).

In heritage conservation and resource management, stakeholders include those affected by, or interacting with, the heritage resources in question (Blundo et al. 2018). The perceptions of stakeholders are a tool used in stakeholder engagement to understand how people value their resources (Carter \& Bramley 2002). Understanding perceptions gives an indication of the actions that should be taken towards resource conservation and management (Bakri et al. 2015). Incorporating perceptions of people into management plans facilitates effective management and subsequently supports the move towards the goal of sustainable development through resource maintenance and conservation (Jaafar, Noor \& Rasoolimanesh 2015). In addition to an improved or maintained state of the environment, well-managed resources may also lead to wider community involvement and greater social cohesion, contributing to sustainable communities (Hribar, Bole \& Pipan 2015).

The significance of resources is attributed according to the value placed by people on heritage resources (The Burra Charter 1999). Heritage value is defined by Díaz-Andreu (2017) as 'the meanings and values that individuals or groups of people bestow on heritage'. Heritage value definitions may differ according to the communities to which people belong, race, gender and other background information (Deacon \& Smeets 2013). Heritage-management plans are important in identifying important resources, understanding their value and significance, as well as provisioning for their protection, use and maintenance in the future.

Goal 11 of the Sustainable Development Goals, adopted by the United Nations in 2015, states the aim to 'make cities and human settlements inclusive, safe, resilient and sustainable'. One of the targets under this goal is to 'strengthen efforts to protect and safeguard the world's cultural and natural heritage' (Patel et al. 2017). Sustainable communities require a just and inclusive decision-making process (Caffyn \& Jobbins 2003). This study aims to contribute to this goal by using stakeholder perceptions in an assessment of the natural and cultural heritage assets for the town of Wakkerstroom, Mpumalanga. This was done in order to make suggestions towards the development of management guidelines for their conservation. There are 10 World Heritage sites in South Africa and numerous national and provincial sites (UNESCO n.d.). One of these provincial sites is the museum town of Pilgrim's Rest in Mpumalanga, which could be referred to as a heritage town (Rahman 2013). Locations such as the Horseshoe Waterfall, Joubert Bridge and the Natural Rock Bridge are all declared as provincial heritage sites in this town by the South African Heritage Resources Agency (SAHRA 2020).

By identifying resources, their uses, conservation issues, as well as stakeholders, stakeholder issues and interests, the development of future management actions aimed at resource conservation and sustainability that can be facilitated. No studies of this sort have been conducted for the town, making outputs of the study valuable for environmental heritage protection in Wakkerstroom, and for other heritage-rich locations. This study aimed to use stakeholder perceptions to contribute to the development of management guidelines for the conservation of heritage resources in the town. In South Africa, the concept of conservation is mostly focused on components of the natural heritage, but this concept can, and should, be extended to include architectural and cultural conservation, in the same location. A seminal work was published by Stubbs (2009) in which he proposed a global view of conservation. This approach has been adopted in several case studies in the USA, the UK, Malaysia and Italy (De Medici \& Senia 2007; Harun 2011; Lapadula \& Quiroga 2012; Pereira \& Marker 2016). This study explicitly includes the conservation of the natural and the architectural and cultural heritage in Wakkerstroom and is one of the first of such studies in South Africa.

\section{Research study site, design and methods Study site}

The study was conducted in Wakkerstroom, a small town in the Mpumalanga province bordering the province of 
KwaZulu-Natal, South Africa, which is part of the Dr Pixley Ka Isaka Seme (DPKIS) Local Municipality. The town was established in 1859 (Theal 2010), occupies an area of 87.68 square kilometres $\left(\mathrm{km}^{2}\right)$ and has a population of approximately 6800 residents (DPKIS Local Municipality IDP 2011). The primary industry is maize, sheep and cattle farming which are conducted at commercial and subsistence levels. The town is one of the oldest towns in the region, and is subsequently rich in heritage, both natural and cultural. The area is home to the Wakkerstroom Wetland Reserve (commonly known as the Vlei) which has a natural heritage status and provides habitats for numerous bird species. The grasslands are also protected by The National Environmental Management Biodiversity Act (Act No. 10 of 2004). The town is inhabited by people of diverse heritage, including the Ndebele, Zulu, Afrikaaner, British and their descendants. There are many farming families (e.g. Uys, Oosthuizen and Greyling) which have been on the same land for seven generations, making it a suitable site for heritage perception exploration (Gardiner 2017). The town consists of a 'township' and 'town' area as a result of segregation during the Apartheid era. The township area is known as Esizameleni, and comprises approximately 1650 Ndebele and Zulu households (DPKIS Local Municipality IDP 2011). This area is primarily characterised by underdevelopment, unemployment, low education levels and low access to adequate sanitation (Jürgens et al. 2013; Kalichman \& Simbayi 2003; Salo 2003; Wood et al. 2010). The town area conversely displays a higher level of development, with a larger number of white Afrikaaner inhabitants (StatsSA 2011). Esizameleni is about $4 \mathrm{~km}$ from the centre of the town.

\section{Study design and methods}

This study was divided into three parts: (1) a desktop study to identify the heritage resources; (2) a stakeholder map created to identify groups of stakeholders and the structure of the community and (3) interviews with stakeholders to assess their perceptions that were used to develop management guidelines for conservation. The desktop study used a variety of sources, including the Wakkerstroom official website (https://www.wakkerstroom.co.za/) and South African History Online (https://www.sahistory.org. $\mathrm{za} /$ ) to obtain baseline information about cultural and natural heritage resources in the town. The register of the South African Heritage Resources Agency (SAHRA Declared Sites 2020) was also consulted for a list of declared sites. Publications from the town including 'Wakkerstroom: Jewel of Mpumalanga' (Hofmeyer, Smith \& Smith 2009) as well as the 'Wakkerstroom; Bird and Nature Guide' (Tarboton 2004) were used to identify sites of heritage importance. Information relating to the location, history and the known uses of the resources was gathered in order to understand the relevance of the heritage resources and aspects identified. A publication titled 'Wakkerstroom: A Conservation Study' (Peters 1995) was also consulted for information on the architecture in the town. A table was constructed summarising the resources identified, the type of resource and the importance or value attributed to the resource.
In order to identify stakeholders who should be interviewed, a stakeholder map was developed with the help of managers of conservation organisations in the town by identifying users of the resources in the communities who would be affected by, or be involved in, changes in the condition of the resources, as well as any management practices implemented. Managers responsible for the protection and monitoring of heritage resources were also identified through various organisations assigned with the task of management of resources in the town. The identified stakeholders were then grouped according to categories that would represent the structure of the community of Wakkerstroom, and ensure that stakeholder groups were adequately represented where resource conservation is concerned according to the best practice of stakeholder engagement as suggested by Hare and Pahl-Wostl (2002). Categories were developed according to where stakeholders lived, and where possible, the economic and organisational role of stakeholders in the community. A stakeholder map was used to document the stakeholders identified and the strength of stakeholder linkages in relation to the main management body which was the DPKIS Local Municipality. This, in conjunction with subsequent interview data also enabled assessment of roles in resource protection, influence in resource conservation and resource-conservation plan execution (Varvasovszky \& Brugha 2000).

Two semi-structured interview questionnaires were used because they allowed for more open-ended questions and the collection of a wider range of information. One questionnaire was used for interviews with community members including business owners, residents from the town and Esizameleni areas of Wakkerstroom. Interviews were conducted in English and isiZulu according to the choice of the participant. The interviews addressed questions related to demographic information, the understanding of heritage and heritage values, identification of resources valued and the reasons for the perceived importance. Use of the resources and participation in heritage activities were also investigated including the contribution of participants to the protection of these resources. Sources of information regarding heritage resource aspects and threats perceived to resources were also addressed by the interview questions.

The second interview questionnaire was addressed to the caretakers and managers of organisations tasked with the preservation of heritage resources in the town in order to gather more information from these stakeholders of the town region regarding resource management. Organisations included Birdlife South Africa, Working on Fire and the Wakkerstroom Natural Heritage Association (WNHA). The second interview instrument was similar to the first, differing only in the addition of questions related to management actions. This was in order to establish current management practices and to use the information gathered in developing suggestions for future management plans.

In both the town and township areas, key informants were initially identified and then snowball sampling was used as 
described by Sadler et al. (2010). In the town area, a total of 15 people were interviewed (including three managers of the aforementioned conservation organisations), whilst 27 people were interviewed from the township area. Interviews were $30 \mathrm{~min}$ long; interviews people in the town area took place at a local hotel restaurant, and interviews in the township were conducted at participant households. A classical 'stakeholder map' as defined in the literature was very difficult to achieve in this small village, as many people, especially those in the town, played multiple roles. They were simultaneously owners of businesses, chairpeople of volunteer organisations and part-time residents. The downside of this may be offset by the fact that many people understood the need for conservation as they were embedded in the activities. The municipality was also contacted for interviews as it was important that they be interviewed; however, they did not respond. Officials in the municipality (e.g. town manager, mayor and chief financial officer) were all struggling with financial compliance in order to prevent intervention by the authorities and had no interest in service delivery or in the conservation of the natural and heritage resources (Municipal Money Profile: Dr Pixley Ka Isaka Seme 2020).

To analyse the data, content analysis was carried out - a method identified to be most effective in describing the qualitative data gathered in this study. Content analysis also lends itself to a quantitative description of the data. Responses from town and township groups of stakeholders were transcribed into two Microsoft Excel spreadsheets. Where applicable, categories were developed with similar themes or answers falling under the same category. Responses were coded according to categories and expressed as percentages within and between categories. Bar graphs were produced for each question, in each area (town or township). Bar graphs of demographic data (average age of participants, education levels and average time participants have lived in the town) were also produced. No statistical tests were conducted on these data as sample sizes were too small.

\section{Results Inventory of heritage resources}

Natural and cultural heritage resources, both intangible and tangible, were identified. Buildings and natural features in the environment were identified (Table 1). Significance was mainly attributed to architectural quality preserved over time and the history of the buildings conferring cultural value.

Three structures listed under national monument status are located in the town. One of these is the Paul Kruger Bridge, referred to as 'The Old Road Bridge', Marthinus Wesselstroom, under the SAHRA monuments register. The bridge is a steel structure spanning 12.2 metres $(\mathrm{m})$ in length built with material imported from Europe (Peters et al. 2001), and is archived under national monument status (Site reference: 9/2/279/0006), declared as a provincial heritage site under SAHRA and listed under grade II heritage protection (Resources significant within the context of a province administered by the relevant Provincial Heritage Authority [PHRA]) (SAHRA Declared Sites 2020).

The second structure is the Old Court House building (Old Magistrates Office, Engelbrecht Street, Wakkerstroom) which dates back to 1897. Similar to the Paul Kruger Bridge, the building is archived under national monument status. The building is also declared under grade II provincial heritage protection as a Provincial Heritage Site (site reference 9/2/279/0002) (SAHRA Declared Sites 2020). The third structure is the St Mark's Anglican Church, also known as the Old Apostolic Church of Africa, dating back to the 1870s. The building, gazetted in 1982, is the third building in the town archived under national monument status and currently declared as a grade II, provincial heritage site (Site reference: 9/2/279/0006-001). The building was erected following the Anglo-Boer War, serving as a residence for an officer who led the British army (South African Heritage Resources

TABLE 1: Heritage resources and activities identified in the town of Wakkerstroom

\begin{tabular}{|c|c|c|}
\hline Heritage resource/activity & Heritage resource type & Importance and value \\
\hline Wakkerstroom Wetland & Natural heritage, Tangible & $\begin{array}{l}\text { Grazing land, Birding, ecosystem services, dependence for water filtering and drinking water, } \\
\text { tourism }\end{array}$ \\
\hline Mountains and hiking trails & Natural heritage, Tangible & Recreational and tourism \\
\hline St Mark's Anglican Church & Cultural heritage, Tangible & Religious and historical importance, architectural value \\
\hline Paul Kruger Bridge & Cultural heritage, Tangible & Historical and religious importance (First Zionist baptismal place) \\
\hline Naderduitse Gereformeerde Kerk & Cultural heritage, Tangible & Historical and religious: Very first Dutch reformed church \\
\hline The Wakkerstroom Cemetery & Cultural heritage, Tangible & $\begin{array}{l}\text { Historical: The burial place of many of the soldiers; of Anglo Boer war and families of } \\
\text { Wakkerstroom residents }\end{array}$ \\
\hline The Old Bank Building & Cultural heritage, Tangible & Historical: First building of the FNB bank \\
\hline The Wakkerstroom Hotel & Cultural heritage, Tangible & Historical: First town hotel with important architectural significance \\
\hline The Roman Catholic Church (St Joseph's Church) & Cultural heritage. Tangible & Historical and architectural value \\
\hline San paintings & Cultural heritage, Tangible & Historical: Left by the San people who were the first inhabitants of the land \\
\hline The Wakkerstroom Cemetery & Cultural heritage, Tangible & British soldier memorial of those who died during the First Boer war over the $1880-1881$ peroid \\
\hline Wakkerstroom music festival & Cultural heritage, Intangible & A showcase of various cultural diversities through song and dance \\
\hline Wakkerstroom arts and crafts ramble & Cultural heritage, Intangible & $\begin{array}{l}\text { A platform for artists to show case crafts linked to culture, national symbols and associated with } \\
\text { various techniques }\end{array}$ \\
\hline
\end{tabular}


Information Systems n.d.). The church is located on Erf 82 Kerk Street, it is privately owned, but local Anglicans still conduct services in the church.

The Wakkerstroom Wetland is one of the most notable natural heritage resources mentioned in the literature on the town. The wetland measures about 1000 hectares (ha) (Begg 1989) and is located at the upper reaches of the Tugela catchment. The wetland does not have a high floral diversity (Kotze, Breen \& Klug 1994) but is dominated by a dense growth of Carex acutiformis (Ehrh.), Phragmites australis (Cav.) Trin. Ex Steud. and Typha capensis (Rohrb.) (Joubert \& Ellery 2013). This wetland is however important as a habitat, and a nesting and foraging area for rare birds such as the White-winged Flufftail (Sarothrura ayresi) (Tarboton 2004), as well as the Grey crowned Crane (Balearica regulorum), both of which are some of the rarest birds in Africa (Khan 2010; Oellermann, Darroch \& Klug 1994; Reid et al. 2005). The wetland attracts multiple bird species from around the world, including migratory birds from Eurasia and intra-African migrants (Joubert \& Ellery 2013). Invertebrate species are well represented, as well as species of fresh-water otters (including the Spotted-necked Otter [Lutra maculicollis]) (Wakkerstroom Bird Club 2016; Zhang et al. 2011).

In addition, the Wakkerstroom vlei is also used as a grazing site for cattle by local farmers (Kotze 2013). Harvesting of plants for medicinal purposes as well as water supply are valued services provided by the vlei. The surrounding grasslands and forests are highly diverse with the species list tally currently at 1300 and further work is under progress (SANBI 2020a).

\section{Stakeholders}

Stakeholders identified included the organisations tasked with the conservation and management of heritage resources in the town of Wakkerstroom. The WNHA together with the Working on Fire programme and BirdLife SA are the main organisations tasked with resource conservation. These organisations mainly focus on the protection of natural heritage resources in the town, including bird and bird habitat conservation, wetland ecosystem protection and fire control in the wetland and grassland areas. These organisations are part of the stakeholders of the heritage resources identified (Figure 1). Although, they are also, part of the town community (as explained earlier), the leaders of these organisations were interviewed separately as they served a management function abrogated by the municipality.

Two main stakeholder groups were identified: the Esizameleni township and the town areas of Wakkerstroom. In the town region, stakeholders included businessmen, residents and tourist stakeholder groups because of the role they played as dominant stakeholder subgroups within the town area. Tourists were included because of the role tourism plays in motivating conservation of the town. These stakeholder groups interact directly with resources, are involved in, impacted and affected by, resource management and conservation in the town, and subsequently have resource management and conservation interests.

In the township area of Esizameleni, the low levels of tourism activity, business operations and interactions with resource conservation activities in Wakkerstroom resulted in no clear subgroups being identified. One group of stakeholders was therefore formed and labelled as 'Residents'. Establishing a 'business people' subgroup similar to that of the town area could not take place in the township stakeholder group. This is because, although there are individuals that manage businesses such as spazas and shebeens in the township, the ownership, longevity and location of these businesses change frequently, making it difficult to identify actors as stakeholder subgroups. A 'Residents' group was therefore perceived as a

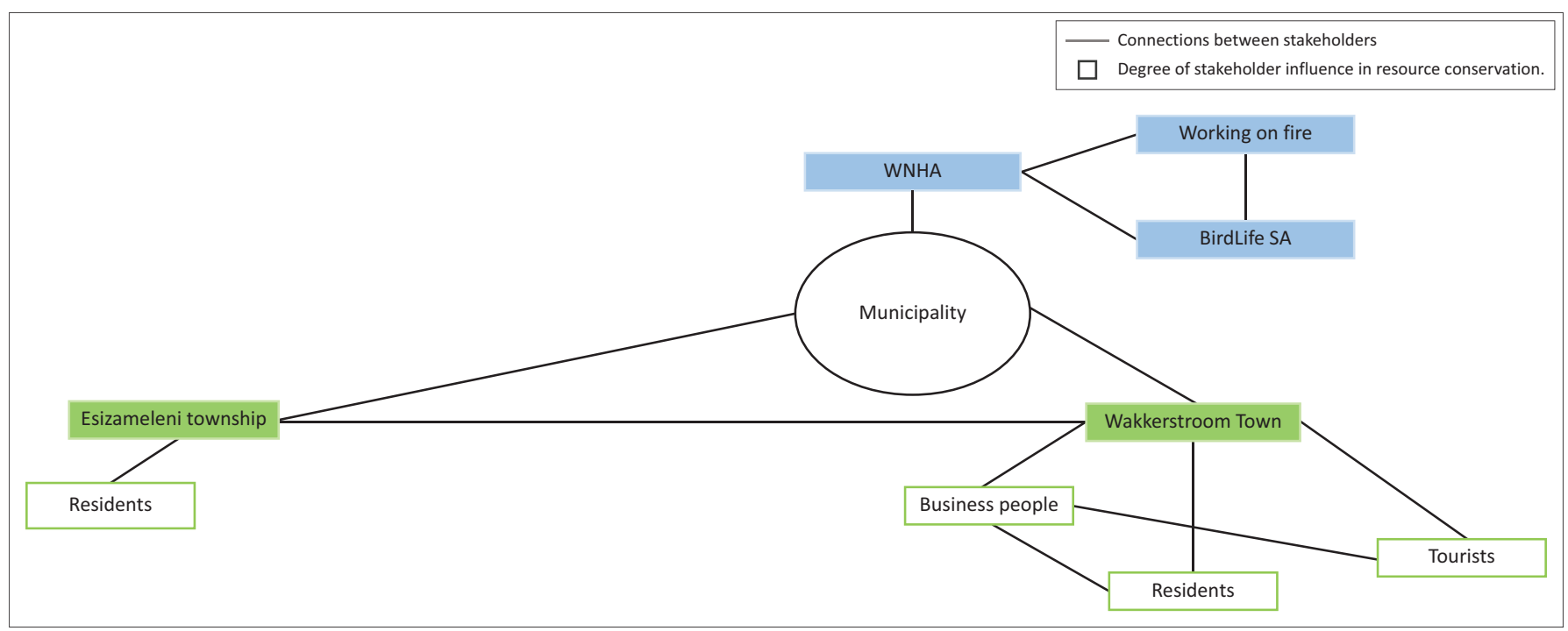

Note: The stakeholder map shows stakeholders and the strength of connections between various stakeholders (line length: Long lines indicate weak connection whilst short lines indicate strong connections). The influence in management actions associated with resource conservation is also shown through box length: Long boxes indicate high influence and short boxes indicate low influence).

FIGURE 1: Stakeholder map. 
representative stakeholder grouping for the purpose of assessing conservation linkages, roles and influence in resource conservation and management.

The DPKIS Local Municipality is included as the main actor in management of resources in the town. The municipality, through its role as government, should serve as the main body to which all other stakeholders are directly or indirectly linked. According to interviews conducted with managers of conservation organisations in Wakkerstroom, people employed by the municipality in the town can, however, be described as relatively inactive, paying little attention to heritage resource conservation in the way of financing and supporting town conservation activities. This leaves the bulk of management to town non-governmental organisations such the WNHAand volunteer work by members of the community, despite the management responsibility of the municipality, by virtue of it being elected.

\section{Stakeholder linkages, their influence and involvement in the conservation of heritage resources}

Although conservation decisions made regarding heritage resources affect all stakeholders identified, the involvement, influence and linkages of stakeholders, and subsequently their roles in resource preservation and management differ (Figure 1). Through interviews, the community of the town area was shown to have a greater involvement in resource conservation and management actions taken, with the residents, those running businesses within the town and part-time residents (people who have holiday homes and visit at different times of the year) playing the biggest role. This means that there is a greater influence of stakeholders in the town area on resources compared to those in the community of Esizameleni.

From interviews conducted, it was evident that the Esizameleni township community plays a small role in conservation actions implemented by the town. This is reiterated by the low representation of this stakeholder group in the heritage conservation organisations of the town.
Stakeholders in the Esizameleni area were found to have little knowledge or involvement in resource conservation activities (Figure 1). Connections between township stakeholders and stakeholders of the town area are also shown to be weak because of the lack of communication and mutual activities between the two stakeholder groups.

\section{Perceptions towards heritage}

The highest level of education amongst participants of the Esizameleni township was found to be a high school qualification (Figure 2a) in contrast to the town area where the highest level of education reported amongst participants reached postgraduate degree levels, and all participants had some level of education (Figure $2 b$ ). Township participants linked heritage definitions mainly to the theme of 'identity' with references to cultural and traditional identities, followed by 'inheritance' alluding to customs and traditional practices passed down through generations (Figure 3a). Town participants associated heritage mainly with the theme of 'inheritance' which denoted the passing down of tangible resources (e.g. natural resources, farms or buildings), generationally (Figure $3 b$ ). Township participants identified threats to heritage under the category of 'people and livestock' (livestock referring to the farming practices associated with keeping livestock) including the negative attitudes towards conservation by town participants as the greatest threats to heritage resources (Figure 4a). Town participants identified mining as the top threat to natural heritage resources (the wetland) followed by concerns about farming practices related to the number of cattle grazing in the wetland, which may lead to overgrazing. Alack of interest in conservation and general pollution were also mentioned as threats (Figure $4 \mathrm{~b}$ ).

\section{The development of management guidelines for heritage resource conservation}

The aim of this study was to understand how stakeholder perceptions (presented above) may contribute to the

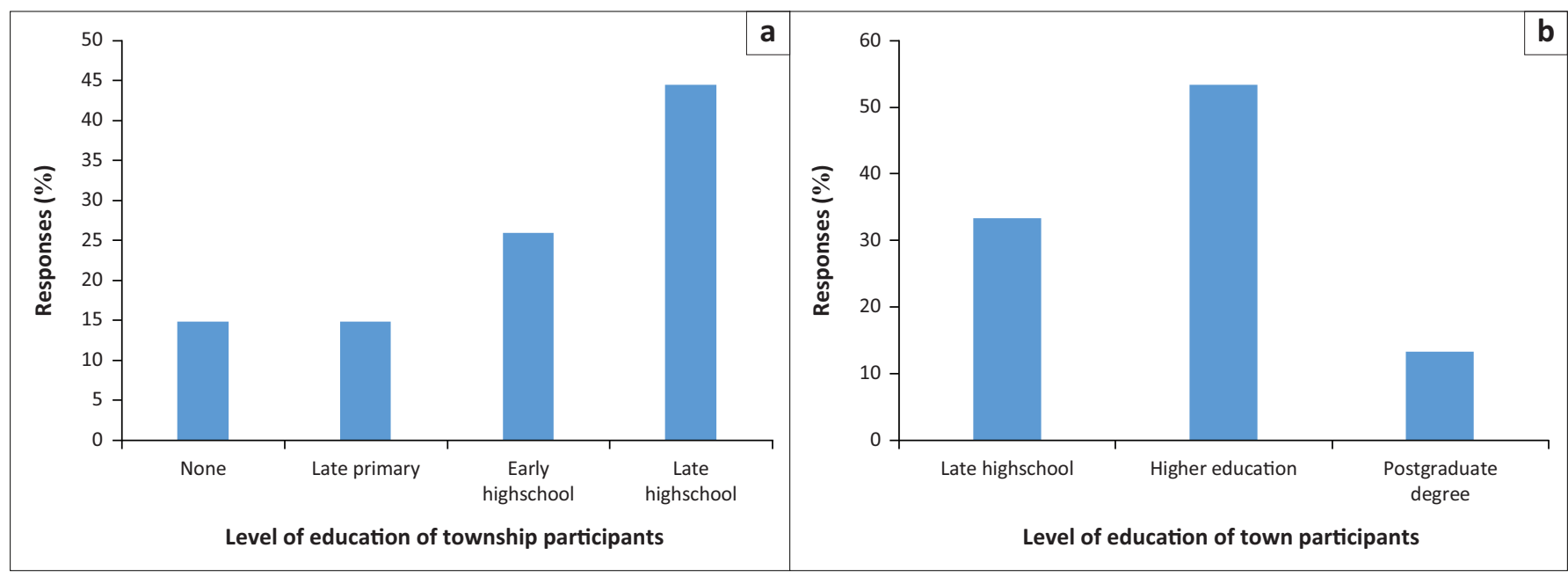

FIGURE 2: Levels of education of participants. The highest levels of education reported by participants in Esizameleni and town communities in Wakkerstroom, Mpumalanga Proportions of responses (\%) ( $y$-axis) against education level ( $x$-axis) are illustrated in the graphs. 'Late high school' (Grade 10-12), 'Early high school' (Grade 8-9), 'Late primary' (Grade 4-7), 'Higher education' (Diplomas and post schooling courses) and 'Postgraduate degrees' were educational categories used for participants. 


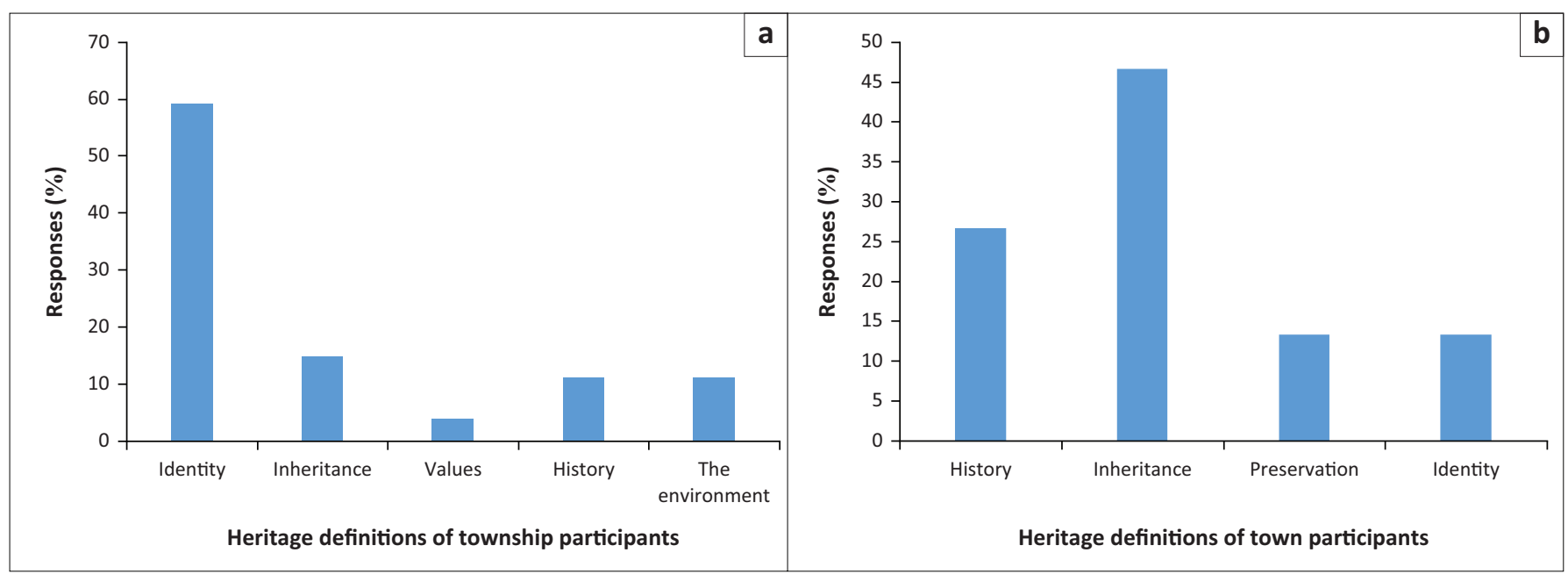

FIGURE 3: Heritage definitions by frequency. The heritage definitions provided for the term 'heritage' by participants in the Esizameleni township and the town area. Proportions of responses ( $y$-axis) amongst participants are shown against the themes of heritage definitions provided ( $x$-axis).

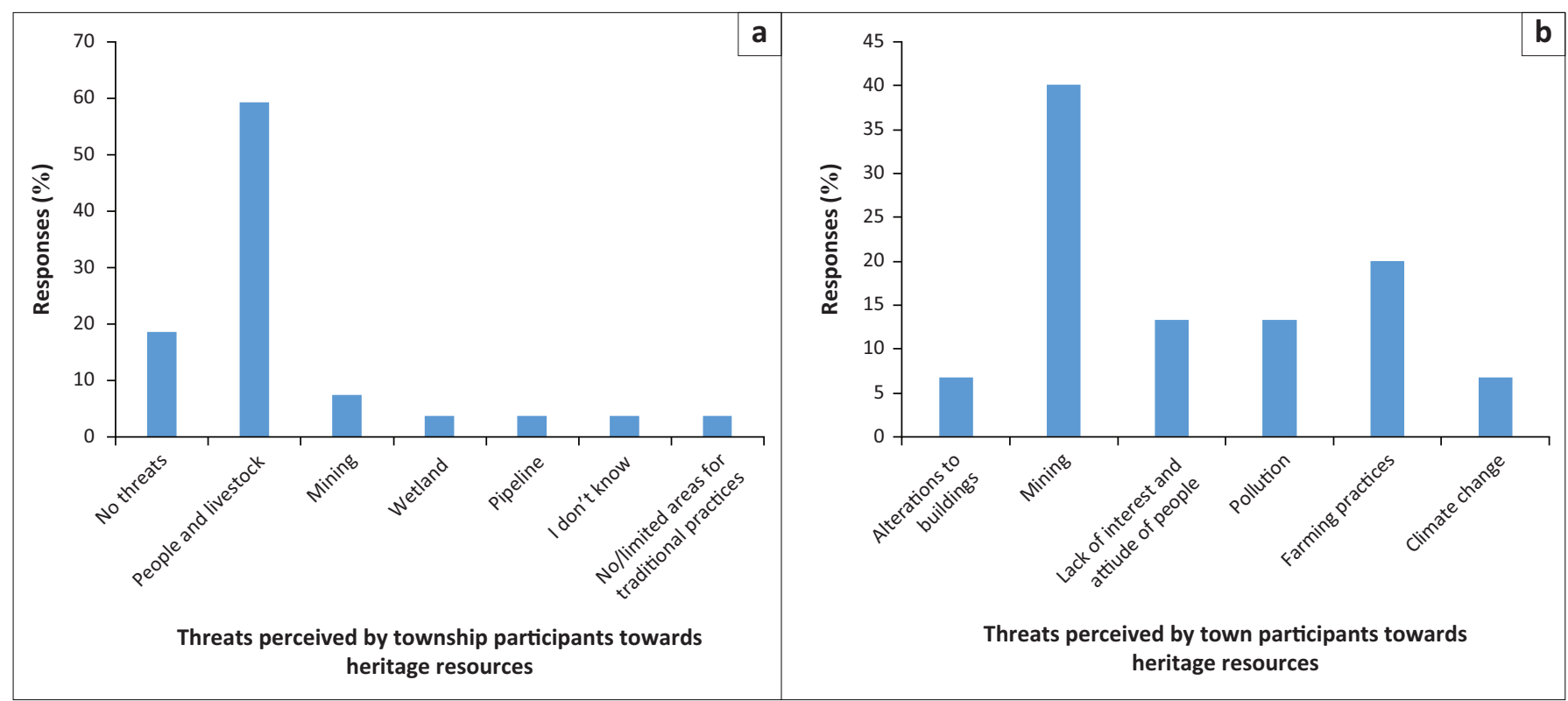

FIGURE 4: Threats identified. Threats to heritage resources identified by participants in the township and town are proportions of threats mentioned (\%) ( $y$-axis), against the threats mentioned by participants ( $x$-axis) are shown. In the township region, 'people and livestock' are of greatest concern. This includes grazing by livestock and littering. In the town region, 'mining' is stated as the greatest concern amongst participants.

development of management guidelines for the conservation of heritage resources in the town of Wakkerstroom, Mpumalanga. The interview responses from the WNHA, Working on Fire and Birdlife SA organisations showed that there is no integrated management plan for the conservation of heritage resources. The municipality, as part of the government, is the main body responsible for the management of heritage resources within towns and townships located within the DPKIS Local municipality (Rautenbach, Hart \& Naudé 2015) but it has abrogated its responsibility for conservation and management of the wetland to the WNHA, which remains legislatively compliant under the National Environmental Act (Act No. 107 of 1998). Interviews also revealed that there are no ongoing conservation activities or management plans associated with the cultural heritage. The only activity, which the WNHA organises for Heritage Day, is a series of guided walks and information brochures to select buildings. There are several conservation projects conducted by the WNHA, but most of these are carried out on an ad hoc basis and do not form part of any management plan which should be developed using a standard framework of setting objectives, time frames, budgets, monitoring and evaluating planned actions and activities.

In terms of some current management actions for conservation, the WNHA reported conservation projects associated with the wetland including monitoring the number of cattle grazing in the vlei, the amount and removal of litter, the removal of invasive alien plants and limited spraying with herbicide to maintain patch diversity. Fires occur frequently in Wakkerstroom. Fire management in the wetland is also undertaken by the WNHA working closely with the Working on Fire organisation. In winter months, fire-breaks prevent the spread of fires and fire damage. Patch burning in the vlei will be monitored to limit the dominance of Phragmites australis. 
Interviews also revealed that the WNHA and BirdLife SA are advocating the wetland be declared a Ramsar site. The Ramsar Convention is targeted towards promoting the conservation and wise use of all wetlands through local and national actions and international cooperation, as a contribution towards achieving sustainable development throughout the world. In South Africa, a wetland can however only be included as a Ramsar Site when declared a protected area under The National Environmental Management: Protected Areas Act (Act No. 57 of 2003). Currently, the wetland is classified as an informally protected area, not yet formally protected by legislation (SANBI 2020).

\section{Discussion}

The study identified a combination of natural and cultural heritage resources in the town of Wakkerstroom; the rich heritage is revealed in the diverse assemblage of heritagerelated sites and activities, linked in many ways to the town's history. The results provide an interesting test case as to whether a single location could be used to show the benefit of a single integrated management plan for the conservation of both the natural and cultural heritage resources. This study provides some preliminary information which would be needed to develop such a plan. The resources are relatively well-defined, which is a first and very important step. The Wakkerstroom Wetland was identified as the main natural heritage resource of importance in the town. In terms of cultural heritage, three sites classified as national heritage resources were identified (the Paul Kruger Bridge, the Old Magistrates Court and St Mark's Anglican Church), along with two annual town heritage festivals of music and crafts which celebrate, through artistic display, the cultures of various inhabitants of the region and beyond. This diversity in cultural and natural heritage, and high historic value of the town, support the proposed classification of the town under the definition of a 'heritage town', as used by Rahman (2013).

The study also highlighted the opportunities and limitations that would need to be considered and included in the development of a management plan. These included value definitions, stakeholder participation in decision-making and engagement in activities, styles of communication, language and awareness; trade-offs needed to achieve sustainable development. Value definitions were found to be different amongst the town and township communities interviewed. The value attributed to heritage amongst township participants related to the importance of heritage in defining identity. This was coupled to the mention of cultural practices and traditions at personal and household levels as important heritage aspects. In the town area, the natural heritage was valued most, with the wetland mentioned as the most important heritage resource. This may be because of the greater interaction the people in the town have with the economic benefits of the wetland through tourism, even though many of the 'bird guides' trained by BirdLife, live in the township. The generational transfer of values was shared across the communities. Both the town and township communities valued the transfer of heritage from one generation to the next despite the differences in the elements of heritage transferred.

Clear divisions were seen in the communities with respect to heritage conservation in the town, and the level of contribution of the various stakeholders to resource conservation efforts. Conservation of heritage resources was found to be focused in the town area with conservation organisations and members of these organisations primarily based in this area. This created a disconnect between township stakeholders and current heritage resource conservation, perpetuating the unequal participation of township stakeholders in conservation efforts by organisations. This supports findings by Chirikure et al. (2010), stating that local communities are not active in conservation efforts. A situation where stakeholders are spectators of resource conservation, where awareness of conservation efforts taking place exists at all, is created (Ndoro, Mumma \& Abungu 2008). This means that stakeholders do not participate in conservation or the decisions surrounding conservation and rather stand back and watch whilst managers or other small groups of authority make important conservation-related decisions and implement these independent of stakeholders.

The unequal participation highlighted in the township negatively impacts the move towards achieving sustainability. Sustainable communities require greater integration in heritage conservation and decision-making in this regard, in order to ensure that efforts taken are effective and far-reaching. Caffyn and Jobbins (2003) also mention the importance of incorporating stakeholders in the establishment of plans before plan implementation. This emphasises the importance of stakeholder participation at all stages of decision-making and management plan development. Greater participation, and therefore, possibly greater conservation of heritage resources would result in better conservation of both natural and cultural heritage types, ensuring their sustainability over time. The involvement of township communities would encourage a more cohesive community approach to conservation, and possibly effect more conscious and careful interactions of township residents with resources such as the natural environment, also promoting sustainability in the future of Wakkerstroom.

Stakeholder perceptions in this study highlighted a lack of communication amongst the two communities. The people in the town valued written communication, whereas the people in the township preferred oral communication in their traditional languages. Communication is an important step towards inclusiveness, sustainable development and effective heritage resource conservation (Aas et al. 2005). A lack of communication has been linked to hampered development in tourism and other developmental activities where towns are concerned (Peters 1999). In order to ensure progression towards a sustainable town where communication is concerned, it is vital that the language 
differences amongst the two stakeholder communities are considered. The creation of awareness, possibly through the education system, and incorporation of more languages in information communication and transfer (i.e. more of the local languages including isiZulu and siSwati) where heritage conservation is concerned is vital for the success of conservation efforts and effective management. Effective communication of heritage conservation-related plans and conservation issues in both the township and town area would facilitate greater community cohesion and facilitate better participatory engagement, contributing to the aim of a sustainable town, and sustainable development (Keitumetse 2011).

A balance between the need for development in the town and the need for heritage conservation is also highlighted by threats such as those of mining mentioned by stakeholders. Whilst some township stakeholders viewed mining as a source of much-needed job creation and development, concerns of damage to the natural environment including the wetland were mentioned by other stakeholders. This creates a conflict between development and heritage protection and presents a challenge to management (Chirikure 2013; Chirikure et al. 2008). Local economic development is mentioned in the Integrated Development Plan, including the prospect of mining the natural resources (mainly coal) in the district and using this as a source of economic development (DPKIS Local Municipality IDP 2017). The IDP recognises under Development Principle 1 the need to achieve a balance between areas of environmental conservation and activities such as mining and tourism (DPKIS Local Municipality 2017). This IDP should be reviewed considering the information collected in this study. Discussions are ongoing with the municipality.

Future participation of communities is important in heritage management and the success of conservation efforts (Yung \& Chan 2011). Through greater participation and inclusion of township stakeholders in conservation actions in the town, the needs of various stakeholders, the differences in values and heritage definitions can be addressed and incorporated into future conservation plans (Richards, Carter \& Sherlock 2004). Incorporating the perceptions of local community stakeholders is important for successful efforts towards sustainable development and sustainable communities to be implemented (Gursoy, Jurowski \& Uysal 2002).

Explicit presentation of benefits of conservation to stakeholders could result in a greater appreciation and participation in conservation efforts. The value of public education has been recognised and should be incorporated in this regard (Azman et al. 2010). Education influences the behaviour of people and actions taken towards conservation (Azman, Halim \& Komoo 2009). Awareness and understanding of heritage have been recognised as important factors to effective conservation, as these facilitate value appreciation.

Consideration and actions towards the declaration of Wakkerstroom as a heritage town could also be undertaken.
Heritage towns are places of great historical value, with multiple historic buildings and areas, and historical events associated with the town. According to UNESCO, a heritage town is characterised by continued use of the town for living purposes, and subsequently, the maintenance of resources, preventing deterioration (Schröder-Esch 2006). Classification of Wakkerstroom as a heritage town will lead to a greater pool of resources becoming available for the conservation of not only the natural heritage in the town, but also the cultural heritage including the town buildings which are national monuments.

Heritage management plans are an important tool and essential for effective conservation. In order to achieve sustainable towns, it is important that all stakeholders take responsibility. The municipality needs to take the leadership in developing the management plan for both natural and cultural heritage conservation, allocating roles for effective implementation.

\section{Conclusion}

The Wakkerstroom area has diverse natural and cultural heritage resources including an internationally recognised wetland with high bird, mammal and reptile diversity as well as it being one of the oldest towns in the region, established in 1859. These attributes suggest that the concept of conservation should embrace both the natural heritage as well as the architectural and cultural heritage, in the same location. This is the trend in many parts of the world, and the results provide an interesting test case as to whether a single location could be used to show the benefit of an integrated management plan for the conservation of both the natural and cultural heritage resources. This study provides some preliminary information which would be needed to develop such a plan, which does seem feasible. The resources are relatively well-defined, which is a first and very important step. There are three buildings that are listed on the South African Monuments register. The study also highlighted the opportunities and limitations which would need to be included in the development of a management plan. These included value definitions, stakeholder participation in decision-making and engagement in activities, styles of communication, language and awareness, trade-offs needed to achieve sustainable development. This study also clearly highlighted the fact that the responsibility for the conservation of these resources is vested in the authoritative power of the elected municipality, but they have abrogated this responsibility. Interestingly this responsibility has been adopted by NGOs. These bodies should work together, using the findings of this study, to turn Wakkerstroom into a 'heritage town' with a sustainable development plan that includes the conservation of both the natural and cultural heritage resources. This would lead to the overall uplift of the community.

\section{Acknowledgements}

The participants of the town and township are thanked for their contributions and hospitality. 


\section{Competing interests}

The authors have declared that no competing interests exist.

\section{Authors' contributions}

M.S. conceived and helped develop the original project. R.M.H.S. carried out the research required on the project under the supervision of M.S. Both authors discussed the results and contributed to the final article.

\section{Ethical consideration}

Ethical clearance for the study was issued by the University of the Witwatersrand (protocol number: HA1905). Informed consent forms were also provided for all participants of the study.

\section{Funding information}

The project was funded by the National Research Foundation and the Department of Science and Technology, through the funding of Prof Scholes' SARChI Chair in Global Change and Systems Analysis (Grant number 101057).

\section{Data availability statement}

The data provided in the paper may be used but the raw data cannot be provided as that is protected by the ethics rules of the university.

\section{Disclaimer}

The views and opinions expressed in this article are those of the authors and do not necessarily reflect the official policy or position of any affiliated agency of the authors.

\section{References}

Aas, C., Ladkin, A. \& Fletcher, J., 2005, 'Stakeholder collaboration and heritage management', Annals of Tourism Research 32(1), 28-48. https://doi.org/10.1016/ j.annals.2004.04.005

Azman, N., Halim, S. \& Komoo, I., 2009, 'Integrated public education for heritage conservation: A case for Langkawi Global Geopark', in G. Ainsworth \& S. Garnett (eds.), Dalam RIMBA: Sustainable forest livelihoods in Malaysia and Australia, pp. 151-156, Universiti Kebangsaan Malaysia, Bangi Malaysia.

Azman, N., Halim, S., Liu, O., Saidin, S. \& Komoo, I., 2010, 'Public education in heritage conservation for geopark community', Procedia-Social and Behavioral Sciences 7 , 504-511. https://doi.org/10.1016/j.sbspro.2010.10.068

Bakri, A., Ibrahim, N., Ahmad, S. \& Zaman, N., 2015, 'Public perception on the cultural significance of heritage buildings in Kuala Lumpur', Procedia - Social and Behavioral Sciences 202, 294-302. https://doi.org/10.1016/j.sbspro.2015.08.233

Begg, G., 1989, The wetlands of Natal: The distribution, extent and status of wetland in the Mfolozi catchment, 68, Natal Town and Regional Planning Commission Pietermaritzburg.

Beierle, T. \& Konisky, D., 2001, 'What are we gaining from stakeholder involvement? Observations from environmental planning in the Great Lakes', Environment, Planning and Conservation 19(4), 515-527. https://doi.org/10.1068/c5s

Blundo, D., Ferrari, A., Del Hoyo, A., Riccardi, M. \& Muina, F., 2018, 'Improving sustainable cultural heritage restoration work through life cycle assessmentbased model', Journal of Cultural Heritage 32, 221-231. https://doi.org/10.1016/j culher.2018.01.008

Caffyn, A. \& Jobbins, G., 2003, Governance capacity and stakeholder interactions in the development and management of coastal tourism: Examples from Morocco and Tunisia, Journal of Sustainable Tourism 11(2-3), 224-245. https://doi. org/10.1080/09669580308667204

Carter, R. \& Bramley, R., 2002, 'Defining heritage values and significance for improved resource management: An application to Australian tourism', International Journal of Heritage Studies 8(3), 175-199. https://doi.org/10.1080/13527250220 000/18895
Chirikure, S., 2013, 'Heritage conservation in Africa: The good, the bad, and the challenges', South African Journal of Science 109(1-2), 1-3.

Chirikure, S., Manyanga, M., Ndoro, W. \& Pwiti, G., 2010, 'Unfulfilled promises? Heritage management and community participation at some of Africa's cultural heritage sites', International Journal of Heritage Studies 16(1-2), 30-44. https:// doi.org/10.1080/13527250903441739

Chirikure, S., Pwiti, G., Damm, C., Folorunso, C.A., Hughes, D.M., Phillips, C. et al., 2008, 'Community involvement in archaeology and cultural heritage management: An assessment from case studies in Southern Africa and elsewhere', Current Anthropology 49(3), 467-485.

Civallero, E., 2007, 'Traditional games, music and oral tradition: Intangible tools in multicultural libraries', in IFLA Satellite Meeting 2007, Conference on Innovative Multicultural Library Services for All, National University of Cordoba, Pretoria, South Africa, August 15-17, 2007, pp. 15-17.

Cleere, H., 2010, 'Management plans for archaeological sites: A world heritage template', Conservation and Management of Archaeological Sites 12(1), 4-12. https://doi.org/10.1179/175355210X12791900195025

Deacon, H. \& Smeets, R., 2013, 'Authenticity, value and community involvement in heritage management under the world heritage and intangible heritage conventions', Heritage \& Society 6(2), 129-143. https://doi.org/10.1179/2159032 X13Z.0000000009

De Medici, S. \& Senia, C., 2007, 'Sustainable requalification of architectural and natural resources: The coastal village of Marzamemi', Ecosystems and Sustainable natural resources: The
Development 4(6), 175.

Díaz-Andreu, M., 2017, 'Heritage values and the public', Journal of Community Archaeology \& Heritage 4(1), 2-6. https://doi.org/10.1080/20518196.2016. 1228213

Dr Pixley Ka Isaka Seme Local Municipality, 2011, IDP, Dr Pixley ka Isaka Seme Local Municipality, Volksrust, Mpumalanga.

Dr Pixley Ka Isaka Seme Local Municipality, 2017, Dr Pixley Ka Isaka Seme Loca Municipality final 2017-2022 Integrated Development Plan (IDP), pp. 2-188, Dr Pixley ka Isaka Seme Local Municipality, Volksrust, Mpumalanga.

Gardiner, N., 2017, A walk through history in Wakkerstroom by: Nicolette Gardiner Wakkerstroom. Wakkerstroom official website, viewed 26 October 2020, from https://www.wakkerstroom.co.za/walk-history-wakkerstroom-nicolettegardiner/.

Gursoy, D., Jurowski, C. \& Uysal, M., 2002, 'Resident attitudes: A structural modeling approach', Annals of Tourism Research 29(1), 79-105. https://doi.org/10.1016/ S0160-7383(01)00028-7

Hare, M. \& Pahl-Wostl, C., 2002, 'Stakeholder categorisation in participatory integrated assessment processes', Integrated Assessment 3(1), 50-62.

Harun, S., 2011, 'Heritage building conservation in Malaysia: Experience and challenges', Procedia Engineering 20, 41-53. https://doi.org/10.1016/j.proeng. 2011.11.137

Hofmeyer, H., Smith, K. \& Smith, C., 2009, Wakkerstroom Jewel of Mpumalanga, pp. 1-191, 1st edn., Mediakor, Johannesburg.

Hribar, M., Bole, D. \& Pipan, P., 2015, 'Sustainable heritage management: Social, economic and other potentials of culture in local development', Social and Behavioral Sciences 188, 103-110. https://doi.org/10.1016/j.sbspro.2015.03.344

Jaafar, M., Noor, S. \& Rasoolimanesh, S., 2015, 'Perception of young local residents toward sustainable conservation programmes: A case study of the Lenggong World Cultural Heritage Site', Tourism Management 48, 154-163. https://doi. org/10.1016/j.tourman.2014.10.018

Joubert, R. \& Ellery, W., 2013, Controls on the formation of Wakkerstroom Vlei, Mpumalanga province, South Africa', African Journal of Aquatic Science 38(2), 135-151. https://doi.org/10.2989/16085914.2012.762897

Jürgens, U., Donaldson, R., Rule, S. \& Bähr, J., 2013, 'Townships in South African citiesliterature review and research perspectives', Habitat International 39, 256-260. https://doi.org/10.1016/j.habitatint.2012.10.011

Kalichman, S. \& Simbayi, L., 2003, 'HIV testing attitudes, AIDS stigma, and voluntary HIV counselling and testing in a black township in Cape Town, South Africa', Sexually Transmitted Infections 79(6), 442-447. https://doi.org/10.1136/sti.79.6.442

Keitumetse, S., 2011, 'Sustainable development and cultural heritage management in Botswana: Towards sustainable communities', Sustainable Development 19(1), 49-59. https://doi.org/10.1002/sd.419

Khan, F., 2010, 'Verlorenvlei: Where past and present collide', Veld \& Flora 96(4), 182-183.

Kirshenblatt-Gimblett, B., 2004 'Intangible heritage as metacultural production', Museum International 56(1-2), 52-65. https://doi.org/10.1111/j.1350-0775. Museum Internd
2004.00458.x

Kotze, D., 2013, 'A system for supporting wetland management decisions', Doctoral dissertation, University of Natal, Pietermaritzurg.

Kotze, D., Breen, C. \& Klug, J., 1994, 'A management plan for Wakkerstroom Vlei', in R.G. Oellermann, M.A.G. Darroch, J.R. Klug \& D.C. Kotze (eds.), Wetland preservation valuation, and management practices applied to wetlands: South African case studies. WRC Report No. 501/5/94, Water Research Commission, Pretoria.

Lapadula, M. \& Quiroga, C., 2012, 'Heritage as a pedagogical resource and platform for exploration in architectural design education', The Journal of Architecture 17(4), 591-607. https://doi.org/10.1080/13602365.2012.709028

Lowenthal, D., 2005, 'Natural and cultural heritage', International Journal of Heritage Studies 11(1), 81-92. https://doi.org/10.1080/13527250500037088

Municipal Money, 2020, Municipal Money Profile: Dr Pixley Ka Isaka Seme, viewed 05 September 2020, from https://municipalmoney.gov.za/profiles/municipalityMP304-dr-pixley-ka-isaka-seme/. 
Munton, R., 2003, 'Deliberative democracy and environmental decision-making', in F. Berkhout, M. Leach \& I. Scoones (eds.), Negotiating change: Advances in environmental social science, pp. 109-136, Edward Elgar, Cheltenham.

Ndoro, W., Mumma, A. \& Abungu, G., 2008, Cultural heritage and the law: Protecting immovable cultural heritage in English speaking sub-Saharan Africa, ICCROM Studies in Conservation, 8, pp. 1-129, International Center for the study of the preservation and restoration of cultural property, Rome Italy.

Nzama, A., 2009, 'The nexus between sustainable livelihoods and ecological management of the World Heritage Sites: lessons from iSimangaliso World Heritage Park, South Africa', Inkanyiso: Journal of Humanities and Social Sciences, 1(1), 34-42. https://doi.org/10.4314/ijhss.v1i1.62107

Oellermann, R., Darroch, M. \& Klug, J., 1994, 'Valuing preferences for wetland preservation: A Wakkerstroom case study', African Journal of Range \& Forage Science 11(3), 89-95. https://doi.org/10.1080/10220119.1994.9647853

Parts, P., Rennu, M., Jääts, L., Matsin, A. \& Metslang, J., 2011, 'Developing sustainable heritage-based livelihoods: an initial study of artisans and their crafts in Viljandi County, Estonia', International Journal of
doi.org/10.1080/13527258.2011.589199

Patel, Z., Greyling, S., Simon, D., Arfvidsson, H., Moodley, N., Primo, N. et al., 2017, 'Local responses to global sustainability agendas: Learning from experimenting 12(5), 785-797. https://doi.org/10.1007/s11625-017-0500-y

Pereira, D. \& Marker, B., 2016, 'The value of original natural stone in the context of architectural heritage', Geosciences 6(1), 13. https://doi.org/10.3390/geosciences 6010013

Peters, H., 1999, 'Making tourism work for heritage preservation: Lijiang, a case study', International Conference on Anthropology, Chinese Society and Tourism, a Yunnan University, Kunming, Yunnan from, September, 1999, p. 28.

Peters, W., 1995, Wakkerstroom: A conservation study, 1st edn., pp. 1-175, Department of Architecture, University of Natal, Durban.

Peters, W., Vicari, P., Nortjie, S., Hewitt, G., Garach, H., Naroth, M. et al., 2001 Wakkerstroom: A re-assessment in urban conservation, 1st edn., pp. 1-131, School of Architecture, University of Natal, Durban.

Rahman, S., 2013, 'Heritage management challenges in historic town of Ludlow, England', World Applied Sciences Journal 24(12), 1589-1596.

Rautenbach, C., Hart, D. \& Naudé, M., 2015, 'Heritage resources management', in A. Du Plessis (ed.), Environmental law and local government in South Africa, pp. 853-885, Juta and Company, Potchefstroom.

Reid, W., Mooney, H., Cropper, A., Capistrano, D., Carpenter, S., Chopra, K. et al., 2005 Ecosystems and human well-being-synthesis: A report of the millennium ecosystem assessment, Island Press, Washington D.C.

Renn, O., 2006, 'Participatory processes for designing environmental policies', Land Use Policy 23, 34-43. https://doi.org/10.1016/j.landusepol.2004.08.005

Richards, C., Carter, C. \& Sherlock, K., 2004, Practical approaches to participation, Macaulay Institute, Aberdeen.

Sadler, G., Lee, H., Lim, R. \& Fullerton, J., 2010, 'Recruitment of hard-to-reach population subgroups via adaptations of the snowball sampling strategy, Nursing \& Health subgroups via adaptations of the snowball sampling strategy, Nursing \&
Sciences 12(3), 369-374. https://doi.org/10.1111/j.1442-2018.2010.00541.x

SAHRA, 2020, Sahris.sahra.org.za. 2020, Declared sites / SAHRA, viewed 26 October 2020, from https://sahris.sahra.org.za/declaredsites.

Salo, E., 2003, 'Negotiating gender and personhood in the new South Africa: Adolescent women and gangsters in Manenberg township on the Cape Flats' European Journal of Cultural Studies 6(3), 345-365. https://doi.org/10.1177/ 13675494030063005

SANBI, 2020a, Plants of Southern Africa: floristic information. Viewed 3 December 2020 from http://newposa.sanbi.org/sanbi/flora.
SANBI, 2020b, Geocortex viewer for HTML5, viewed 17 August 2020, from https:// bgisviewer.sanbi.org/Html5Viewer/Index.html?configBase=http://bgisviewer. sanbi.org/Geocortex/Essentials/REST/sites/MBCP themes/viewers/MBSP/ sanbi.org/Geocortex/Ess/.
virtualdirectory/Resources/.

Schröder-Esch, S., 2006, Practical aspects of cultural heritage: Presentation, revaluation, development; contributions presented on the 28th and 29th October 2005 as Part of the 2nd Hermes Symposium in Krakow, Poland, Bauhaus-University.

South African Heritage Resources Information Systems, n.d., Old apostolic church of Africa, Church Street, Wakkerstroom / SAHRA, viewed 21 February 2020, from https://sahris.sahra.org.za/node/33735.

StatsSA, 2011, Main place: Wakkerstroom, viewed 25 October 2020, from https:// www.statssa.gov.za/?page_id=4286\&id=11493.

Stubbs, J., 2009, Time honored: A global view of architectural conservation, John Wiley \& Sons, Hoboken New Jersey.

Su, M., Sun, Y., Min, Q. \& Jiao, W., 2018, 'A community livelihood approach to agricultural heritage system conservation and tourism development: Xuanhua Grape Garden urban agricultural heritage site, Hebei Province of China', Sustainability 10(2), 361.

Sultana, P. \& Abeyasekera, S., 2008, 'Effectiveness of participatory planning for community management of fisheries in Bangladesh', Journal of Environmental Management 86, 201-213. https://doi.org/10.1016/j.jenvman.2006.12.027

Tarboton, W., 2004, Wakkerstroom bird \& nature guide, S.n., Wakkerstroom.

Theal, G., 2010, History of South Africa since September 1795, Cambridge University Press, Cambridge, England.

The Burra Charter, 1999, The Australia ICOMOS charter for places of cultura significance, Australia ICOMOS, Burwood.

UNCED, 1992, Agenda 21: Programme for action for sustainable development, United Nations Conference on the Environment and Development, Rio de Janeiro.

UNESCO, n.d., South Africa - UNESCO World Heritage Centre, viewed 25 October 2020, from https://whc.unesco.org/en/statesparties/za.

United Nations Educational, Scientific and Cultural Organisation (UNESCO), 1989, Legal instruments. recommendation on the safeguarding of traditional culture and folklore, Paris, 25th General Conference, viewed 25 October 2020, from https://portal.unesco.org/en/ev.php-URL_ID =13141\&URL_DO=DO https://portal.unesco.org/en/
TOPIC\&URL SECTION=201.html.

Varvasovszky, Z. \& Brugha, R., 2000, 'How to do (or not to do). A stakeholder analysis', Health, Policy and Planning 15(3), 338-345. https://doi.org/10.1093/heapol/ 15.3.338

Wakkerstroom Bird Club, 2016, Newsletter, 44, viewed 03 September 2020, from https://www.wakkerstroom.co.za/wp-content/uploads/2014/10/NewsletterNo-44.pdf.

Wood, R., Liang, H., Wu, H., Middelkoop, K., Oni, T., Rangaka, M. et al., 2010, 'Changing prevalence of tuberculosis infection with increasing age in high-burden townships in South Africa', The International Journal of Tuberculosis and Lung Disease 14(4), 406-412.

Young, J., Jordon, A., Searle, R., Butler, A., Chapman, D., Simmons, P. et al., 2013, 'Does stakeholder involvement really benefit biodiversity conservation?', Biological Conservation 158, 59-70. https://doi.org/10.1016/j.biocon.2012.08.018

Yung, E. \& Chan, E., 2011, 'Problem issues of public participation in built-heritage conservation: Two controversial cases in Hong Kong', Habitat International 35(3), 457-466. https://doi.org/10.1016/j.habitatint.2010.12.004

Zhang, Y., Lu, D., Yang, B., Sun, C. \& Sun, M., 2011, 'Coastal wetland vegetation classification with a Landsat Thematic Mapper image', International Journal of Remote Sensing 32(2), 545-561. https://doi.org/10.1080/01431160903475241 